\title{
HOMEOSTASIS MODEL ASSESSMENT - INSULIN RESISTANCE AND SENSITIVITY (HOMA-IR AND IS) INDEX IN OVERWEIGHT CHILDREN BORN SMALL FOR GESTATIONAL AGE (SGA)
}

\author{
Aleksandra Janchevska ${ }^{1}$, Zoran Gucev ${ }^{1}$, Velibor Tasic ${ }^{1}$, Momir Polenakovic ${ }^{2}$ \\ ${ }^{1}$ University Children's Hospital, Medical Faculty Skopje, Republic of Macedonia \\ ${ }^{2}$ Macedonian Academy of Siences and Arts, Skopje, Republic of Macedonia
}

Corresponding author: Aleksandra Janchevska, University Children's Hospital Skopje, Macedonia, Medical Faculty Skopje, Republic of Macedonia, Mother Teresa 17, 1000 Skopje, Macedonia, Email: dr.sasha1969@yahoo.com

\section{ABSTRACT}

Introduction: Children born small for gestational age (SGA) have increased prevalence of metabolic syndrome, diabetes mellitus type 2 (DM2), hypertension and cardiovascular and cerebrovascular events in adulthood.

Patients and Methods: In 100 children born SGA, and in second cohort having 32 obese children born in term with normal birth weight and height, anthropometric measurements and biochemical metabolic profiles were analysed. The Homeostasis Model Assessment - Insulin Resistance and Sensitivity (HOMA-IR and IS) were calculated.

Results: Four overweight/obese children (M:F=3:1) with normal height were found among 100 SGA children. The body mass index (BMI) in all 4 children was above the 98th percentile and the mean BMI z-score was (2.04 $\pm 0.30 \mathrm{SDS})$. The HOMA-IR index in all four children was increased: 1.26-2.65 (>1). Two teenagers had significant hyperinsulinemia $(198.00 \mathrm{uIU} / \mathrm{ml}$ and $275 \mathrm{uIU} / \mathrm{ml})$ and were treated with metformin. Two girls needed only a diet and increased physical activity. The mean values of HOMA-IR $(1.26-2.65 ; \mathrm{N}<1)$ and IS $(58 \pm 17.12)$ in fo-ur SGA overweight/obese children who caught-up growth had indistinguishable values with the group of $32(\mathrm{M}: \mathrm{F}=21: 11)$ obese children (HOMA-IR 1.83 $\pm 1.2 \mathrm{SDS}$; IS $82.99 \pm 64.53$ SDS) born in term with normal birth weight and height.

Conclusions: SGA born children are usually thin; nevertheless we found overweight and obesity in $4 \%$ of the patients. Two of those children have metabolic syndrome. Excess weight, obesity and metabolic syndrome in SGA children result with increase of their inherent risk for DM2, cardiovascular and cerebrovascular diseases in adulthood.

Keywords: small for gestational age, overweight, obesity, cardiovascular and cerebrovascular diseases, type 2 diabetes mellitus

\section{INTRODUCTION}

Worldwide, there were $15.5 \%$ of children born on term with body weight (BW) less than 2500 grams (WHO and UNICEF) [1]. Developing countries had higher SGA incidence, $16.5 \%$ compared to the developed countries 5-7\%. [1-4] In fact, worldwide there are more than 2 million children born with low birth weight (LBW) yearly. [1] About $10 \%$ of SGA children remain short after the age of 4 years. SGA children have a higher risk for obesity, hypertension and insulin resistance during childhood and adolescence and diabetes, osteoporosis and cardiovascular and 
cerebrovascular diseases in adult age [5]. Obesity is an additional risk factor for all those SGA consequences. There are more than 2.1 billion adults and children on Earth who are overweight or obese. [6] An estimated worldwide prevalence of obesity in children and adolescents aged 2-19 years was $5 \%$, or about 110 million. [7]

Body mass index (BMI) in adults less than $18.5 \mathrm{~kg} / \mathrm{m} 2$ is considered underweight, BMI $18.5-24.9 \mathrm{~kg} / \mathrm{m} 2$ is within normal weight range, overweight if BMI is $25-29.9 \mathrm{~kg} / \mathrm{m} 2$, obese if BMI $\geq 30 \mathrm{~kg} / \mathrm{m} 2$, and BMI above $40 \mathrm{~kg} / \mathrm{m} 2$ is extremely obese (WHO classification). [8] For children, the BMI z-score for sex, age and ethnicity is more precise and a more often used tool than BMI. Children with body mass index (BMI) at or above the 95th percentile are considered to be "overweight" (2007 WHO Reference).

\section{PATIENTS AND METHODS}

100 children born SGA in term, irrespective whether they caught up appropriate height after the age of 4 years, were investigated. SGA was defined as BW and/or BL at least 2 standard deviations (SD) below the mean for gestational age (GA). [9] A second cohort was 32 obese children born in term with normal birth weight and lenght and height.

Birth length (BL), birth weight (BW), BL standard deviation score (SDS) and BW SDS, as well as chronological age, gender, height, weight, body mass index (BMI) and BMI z-score was assessed in all children. A Harpenden stadiometer, a wall mounted digital rod, was used for measurement of height. Weight was determined with a precision scale.

Oral glucose tolerance test (OGTT) was done in owerweight and obese children. The definiti-on for impaired fasting glycaemia (IFG) was fasting blood glucose $>6.1$ and $<7.0 \mathrm{mmol} / \mathrm{l}$, while the definition of impaired glucose tolerance (IGT) was fasting plasma glucose $<7.0$ $\mathrm{mmol} / \mathrm{l}$ and the 2-hour sample 7.8-11.1 $\mathrm{mmol} / 1$ (WHO 2007, ADA 2005). [10, 11]

IInsulin secretion and sensitivity was estimated by the Homeostasis Model Assessment (HOMA). HOMA2 model based on non-linear solutions is widely accepted. [12, 13] Values of HOMA-IR and IS are dependent on ethnicity, gender, age, metabolic state of the investigated patient and the clinical methods of calculation. Therefore, cut-off levels are difficult to compare among publications. [14, 15] A standard version of the HOMA Calculator is using a computerised HOMA2 model for estimation of insulin resistance (HOMA-IR) and insulin sensitivity (IS) from fasting plasma glucose and fasting plasma insulin concentrations.

\section{Statistical analysis}

The Kolmogorov-Smirnov test (KS test) is used to check whether the values have normal (Gaussian) distribution. A confidence interval (CI) is calculated for the mean of each of the quantities. For the comparison of 2 groups, Fisher's test is used to check the equivalence of variances. The result of this test is relevant for applying the test for equivalence of means. If the 2 samples have a size greater than 30 , the z-test is used, otherwise the t-test. All tests are with 99\% significance or $\alpha=0.01$.

\section{RESULTS}

Our cohort of 100 SGA children consists of $64(64 \%)$ short children and $36(36 \%)$ children who managed to catch up growth after $4 y$ of age. In the 36/100 SGA born children four were overweight or obese. Those 32 SGA born non-obese children who caught-up growth $(\mathrm{M}: \mathrm{F}=12: 20)$ had $\mathrm{BW}(2490 \mathrm{~cm} \pm 2.19 \mathrm{SDS})$ and $\mathrm{BL}(50.97 \mathrm{~cm} \pm 1.58$ SDS), their mean height was $(118.51 \mathrm{~cm} \pm 0.10$ SDS), weight $(23.18 \mathrm{~kg} \pm 0.01 \mathrm{SDS})$ and BMI z-score $(-0.24 \pm 1.61 \mathrm{SDS})$ (Table 1$)$.

The control group of 35 children $(\mathrm{M}: \mathrm{F}=13: 22)$ born appropriate for gestational age (AGA; BW (3572.22gr $\pm 0.21 \mathrm{SDS}), \mathrm{BL}$ $(50.97 \mathrm{~cm} \pm 0.41 \mathrm{SDS})$ had appropriate for age and sex weight, height, BMI (height $140.70 \mathrm{~cm} \pm 0.92$ SDS), weight (41.60kg $\pm 2.18 \mathrm{SDS})$ and BMI z-score $(0.70 \pm 0.62$ SDS) (Table 1).

In addition, a fourth group of children were obese. Those 32 children $(\mathrm{M}: \mathrm{F}=21: 11$; mean age 11.7 year, within range 5.3-15.41y) were born in term AGA (birth weight 3399.76gr \pm 0.01 SDS), birth length $(51.32 \mathrm{~cm} \pm 0.66$ SDS $)$ (Table 1). Kolmogorov-Smirnov test (KS-test) showed normal distribution of values in all four groups.

Those four $(4.0 \%)$ SGA children caught up growth by the fourth year, but their weight were 
above normal sex and age-related standards. Mean BW was 2665gr \pm 181.0 SDS and BW SDS was $(-1.89 \pm 0.31$ SDS $)$, while BL was $(46.75 \mathrm{~cm} \pm 0.95$ SDS) and BL SDS (-1.78 \pm 0.48 SDS). Three girls and a boy were overweight with BMI above the 98th percentile, and mean BMI z-score $(2.04 \pm 0.30$ SDS) for age and sex. Two girls aged $6.6 y$ and 8.15y had BMI-z score 2.25 and 1.73. Further, a boy aged 14,25y and girl 14,85y had BMI z-score 2.36 and 1.83 for age and sex. Therefore, the 3 girls were overweight and the boy was obese (2007 WHO Reference). It is noted that the BMI $\mathrm{Z}$-score values in obese children were similar to those seen in SGA overweight/obese children (2.39 versus 2.04) (table 1 ).

None of four children had impaired fasting glycaemia. Glycaemia at the $2 \mathrm{~h}$ sample was within normal range: $4.42-5.86 \mathrm{mmol} / \mathrm{l}$. Normal HOMA-IR value is 1 , values above 1 are conside-red abnormal. HOMA-IR index in all 4 children was high: 1.26-2.65. Three girls had HOMA-IR values from 1.26 to 1.79 , and the boy 2.65 . The calculated value of IS in the four obese children was significantly decreased: $37.80-79.60 \%$.
Strikingly, mean values of HOMA-IR ( $p$-value 0.97 ) and insulin sensitivity ( $p$-value 0.45 ) in four SGA overweight/obese children with normal height were similar with the estimated values of 2 parameters in a group of obese children (table 2 and Figures 1 and 2).

Two teenagers, a boy aged $14,25 \mathrm{y}$ and a girl $14,85 \mathrm{y}$, had very high insulin concentration of $275.00 \mathrm{uIU} / \mathrm{ml}$ and $198 \mathrm{uIU} / \mathrm{ml}$ at $2 \mathrm{~h}$ of OGTT and were treated with metformin. Those two chilren had acanthosis nigricans, striae and central fat distribution. The girls aged 6.6 and 8.15 year, had hyperinsulinemia of 77.50 and $70.20 \mathrm{uIU} / \mathrm{ml}$ and got a recommendation for a dietary regime and physical activity. HbAlc values in all four children were within normal range $(\mathrm{N}<5.7 \%)$.

Impaired fasting glycaemia has not been detected in a group of obese children as well as in overweight/obese SGA born children. In 31 obese children the value of glycaemia at $2 \mathrm{~h}$ was within the normal reference range, with the exception of an 8-year-old girl with a value 8.1 $\mathrm{mmol} / \mathrm{l}$. In addition the obese children had normal HbAlc, values.

Table 1. Birth weight $(B W), B W$ standard deviation score (SDS), birth length (BL) and BL SDS, height (H) and height SDS (H SDS), weight $(W)$ and weight SDS (W SDS), BMI and BMI z-score in 4 groups of children: $S G A$ overweight/obese children with normal height, 32 SGA children with normal height, but not obese, 35 children born appropriate for gestational age (AGA) and 32 obese children

\begin{tabular}{|c|c|c|c|c|c|c|c|c|c|}
\hline \multirow{2}{*}{\multicolumn{2}{|c|}{ EARAUPS }} & \multicolumn{2}{|c|}{$\begin{array}{l}\text { SGA overweight } \\
\text { /obese children }\end{array}$} & \multicolumn{2}{|c|}{$\begin{array}{l}\text { SGA children } \\
\text { with } \\
\text { normal weight } \\
\text { and height }\end{array}$} & \multicolumn{2}{|l|}{ AGA } & \multicolumn{2}{|c|}{ Obese children } \\
\hline & & mean & $\begin{array}{c}\mathrm{p}- \\
\text { value }\end{array}$ & mean & $\begin{array}{c}\text { p- } \\
\text { value }\end{array}$ & mean & $\begin{array}{c}\text { p- } \\
\text { value }\end{array}$ & mean & $\begin{array}{c}\mathrm{p}- \\
\text { value }\end{array}$ \\
\hline BW & $\mathrm{gr}$ & $2665 \pm 181.0$ & 0.68 & $\begin{array}{c}2490 \\
\pm 321.87\end{array}$ & 0.98 & $\begin{array}{l}3572.22 \\
\pm 451.30\end{array}$ & 0.91 & $\begin{array}{l}3399.76 \\
\pm 475.22\end{array}$ & 0.91 \\
\hline BW SDS & - & $-1.89 \pm 0.31$ & 0.89 & $\begin{array}{l}-2.19 \\
\pm 0.57\end{array}$ & 0.49 & $0.21 \pm 0.96$ & 0.98 & $-0.06 \pm 0.78$ & 0.88 \\
\hline BL & $\mathrm{cm}$ & $46.75 \pm 0.95$ & 0.94 & $\begin{array}{l}46.62 \\
\pm 2.23\end{array}$ & 0.90 & $50.97 \pm 1.23$ & 0.56 & $51.32 \pm 1.99$ & 0.57 \\
\hline BL SDS & - & $-1.78 \pm 0.48$ & 0.58 & $\begin{array}{l}-1.58 \\
\pm 1.17\end{array}$ & 0.97 & $0.41 \pm 2.15$ & 0.85 & $0.7 \pm 0.99$ & 0.99 \\
\hline $\mathbf{H}$ & $\mathrm{cm}$ & $150.42 \pm 14.97$ & 0.93 & $\begin{array}{l}118.41 \\
\pm 16.65\end{array}$ & 0.70 & $140.70 \pm 21.75$ & 0.83 & $149.94 \pm 16.78$ & 0.50 \\
\hline H SDS & - & $1.04 \pm 1.51$ & 0.86 & $\begin{array}{c}0.10 \\
\pm 1.14\end{array}$ & 0.67 & $0.86 \pm 1.10$ & 0.78 & $1.52 \pm 1.61$ & 0.95 \\
\hline w & kg & $63.2 \pm 23.97$ & 0.98 & $\begin{array}{l}23.18 \\
\pm 9.61\end{array}$ & 0.44 & $41.60 \pm 18.13$ & 0.73 & $69.4 \pm 20.51$ & 0.94 \\
\hline WSDS & - & $2.64 \pm 0.47$ & 0.88 & $\begin{array}{l}-0.01 \\
\pm 1.54\end{array}$ & 0.73 & $2.01 \pm 2.30$ & 0.88 & $7.64 \pm 4.14$ & 0.32 \\
\hline BMI & $\mathrm{kg} / \mathrm{m}^{2}$ & $27.09 \pm 5.63$ & 0.79 & $\begin{array}{l}16.06 \\
\pm 2.26\end{array}$ & 0.95 & $20.19 \pm 4.52$ & 0.38 & $30.22 \pm 4.56$ & 0.09 \\
\hline $\begin{array}{l}\text { BMI Z- } \\
\text { score }\end{array}$ & - & $2.04 \pm 0.30$ & 0.79 & $\begin{array}{l}-0.24 \\
\pm 1.61\end{array}$ & 0.54 & $0.70 \pm 1.01$ & 0.59 & $2.39 \pm 0.62$ & 0.50 \\
\hline \multirow{2}{*}{ Patients } & M & \multicolumn{2}{|l|}{$n=1$} & \multicolumn{2}{|c|}{$n=12$} & \multicolumn{2}{|l|}{$n=13$} & \multicolumn{2}{|l|}{$n=21$} \\
\hline & $\mathbf{F}$ & \multicolumn{2}{|l|}{$n=3$} & \multicolumn{2}{|c|}{$n=20$} & \multicolumn{2}{|l|}{$n=22$} & \multicolumn{2}{|l|}{$n=11$} \\
\hline
\end{tabular}


Table 2. HOMA-IR and Insulin sensitivity estimated values in 2 groups of children: group of 4 SGA overweight/obese children and group of 32 obese children

\begin{tabular}{|c|c|c|c|c|c|c|c|}
\hline \multirow[b]{2}{*}{ PARAMETERS } & UPS & \multicolumn{3}{|c|}{$\begin{array}{l}\text { SGA overweight } \\
\text { /obese children }\end{array}$} & \multicolumn{3}{|c|}{ Obesechildren } \\
\hline & & mean & p-value & $\mathrm{Cl} 99 \%$ & mean & p-value & $\mathrm{Cl} 99 \%$ \\
\hline HOMA-IR & - & $1.85 \pm 0.58$ & 0.79 & $0.15 \div 3.54$ & $1.83 \pm 1.2$ & 0.52 & $1.29 \div 2.36$ \\
\hline $\begin{array}{l}\text { Insulin } \\
\text { Sensitivity }\end{array}$ & $\%$ & $58 \pm 17.12$ & 0.94 & $7.99 \div 108.00$ & $82.99 \pm 64.33$ & 0.08 & $54.48 \div 111.5 c$ \\
\hline
\end{tabular}

Boxplot за HOMA-IR

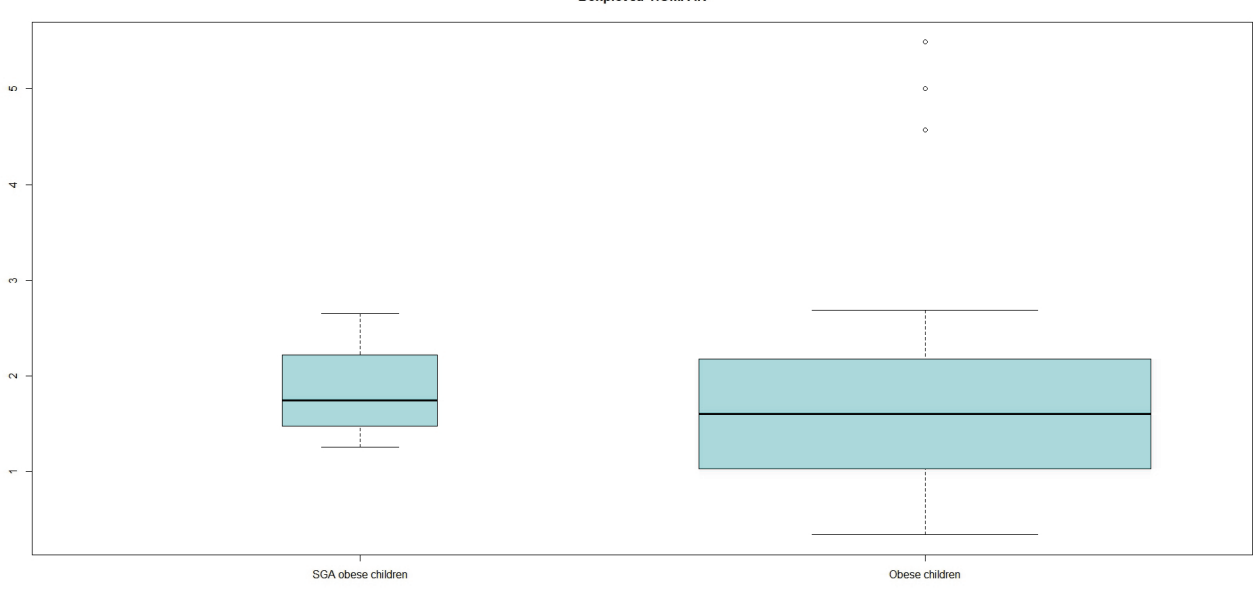

Figure 1. Boxplot for HOMA-IR

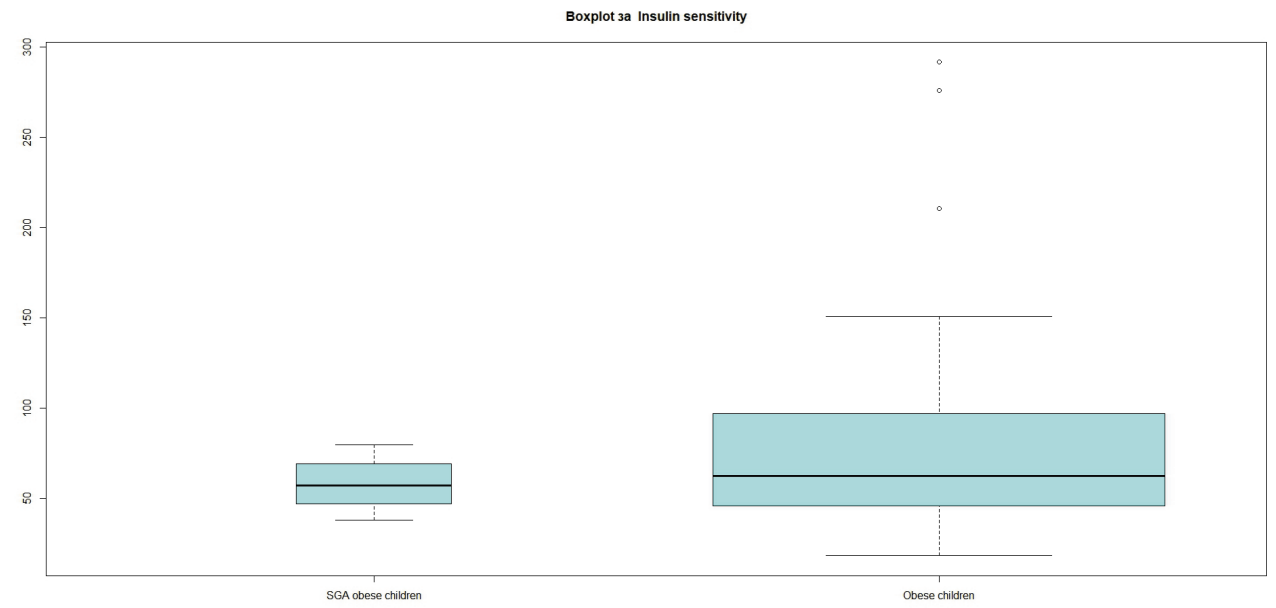

Figure 2. Boxplot for Insulin Sensitivity

\section{DISCUSSION}

SGA born children are usually thin regardless of their height or sex. Increased BMI is rare and predominantly found in girls. [16, 17]. Longitudinal analysys in Italian children observed a tendency of weight gain in childhood in SGA born children compared to their AGA peers. After 2 years of age SGA children are found to be overweight/obese 5-6 times more than their AGA peers $(5.2 \%$ at 2 years versus $29.12 \%$ at 10 y). [18] Again, this is more frequent in girls.

In 18 SGA born girls in term, who caughtup growth and 13 AGA girls aged between 2 and 8 year with normal height, there were no diferences in auxology parameters at the age of $2 y$. 
[19] However, increased body and visceral adiposity and metabolic disturbancies have been detected at the age of 8y only in SGA born girls.

In 111 SGA children (with and without catch-up growth) and 52 AGA born children the highest BMI SDS values with increased body and visceral fat were found in group of 40 SGA born children (M:F=17:23) who caught up growth and weight by the age of two year. [20]

A study performed in young adults aged around 20y born IUGR have shown higher mean BMI and triglyceride values with decreased insulin sensitivity as early signs of impaired glucose metabolism. [21]

We also observed higher frequency of overweight/obese children among girls (3:1). They were all children who cought-up growth measured at the age of referral. The height, weight and BMI z-scores values in all 4 overweight/obese SGA children were comparable with BMI z-scores values of the group of 32 obese children.

A three-fold increased metabolic disturbances in AGA obese children, twice-fold in SGA children compared to the AGA non obese children were reported. [22]

Deng et al. [2012; 20] found significantly higher values of HOMA-IR in SGA born children which caught up growth by 2 years of age, compared to AGA children. The insulin resistance increased with height and BMI catch-up growth in SGA born children. Values of HOMA-IR index in SGA born children without catch up growth have been comparable to HOMA-IR values in AGA born children.

Others have shown similar glucose homeosthasis in SGA children before and after cessation of treatment with growth hormone $(\mathrm{GH})$ $[23,24]$. The insulin resistance was found in $8 \%$ of short SGA born children before the GH treatment and in $10 \%$ of patients 6 months after discontinuation of GH treatment. [23] SGA born young adults have had similar fat mass distribution 5 years after discontinuation of GH treatment, insulin sensitivity and pancreatic $\beta$-cell function with the group of untreated short SGA adults. [24]

In this study of two groups of children with excessive weight gain (the 4 overweight/obese SGA born children with catch up growth and group of 32 obese children) the results of HOMA-IR in both groups were abnormal with decreased insulin sensitivity.
The difficulties in diagnosing metabolic syndrome (MetS) are widely discussed. [25] Strikingly, only $2 \%$ of patients [26] met the criteria although overall prevalence of MetS in children and adolescents ranged between $6 \%$ and $39 \%$. [26] The metabolic syndrome diag-nostic criteria (at least 3) [25] we found that $2 / 4$ overweight/obese SGA born children children fulfilled at least 3 criteria. In fact, all 4 children have BMI greater than the 98th percentile with abdominal fat tissue distribution, 2 of them have BMI $z$-score $>2$ SDS $(+2.25$ and +2.36 SDS $)$, but the other 2 children have BMI z-score between 1.5-2.0 SDS (1.73 and 1.83 SDS), HOMA-IR in all 4 children is also abnormal, 1 child had HOMA-IR 1.25 and 3 children between 1.72.65 , and 2 children have insulin $>104 \mathrm{uIU} / \mathrm{ml}$ (198.00 and 275.00).

\section{CONCLUSIONS}

Contrary to the perception of lean SGA children, some SGA children are overweight or obese. They often have metabolic syndrome, increased insulin resistance and decreased insulin sensitivity. Therefore, their inherent risk of late severe complications is significantly increased. A follow-up and counceling would help decrease the chances of severe late complications.

Supported by a grant from the International Centre for Genetic Engineering and Biotechnology, ICGEB Ref. No. CRP/MAC13-01

\section{Acknowledgements}

We would like to express our enormous gratitude to Ms. Liljana Tasevska-Rmush, molecular biologist and Ms. Olivera Jordanova, MD, Specialist on Clinical Biochemistry for their continued and generous collaboration during the research study.

\section{REFERENCES}

1. WHO and UNICEF report. Low Birthweight Country, Regional and Global Estimates. - by UNICEF, 2004.

2. Alkalay AL, Graham Jr JM, Pomerance JJ. Evaluation of neonates born with intrauterine growth 
retardation: review and practise guidelines. J Perinatol 1998; 18: 142-151.

3. Hediger ML, Overpeck MD, Maurer KR et al. Growth of infants and young children born small or large for gestational age: findings from the Third National Health and Nutrition Examination Survey. Arch Pediatr Adolesc Med 1998; 152: $1225-1231$.

4. Rapaport R, Tuvemo T. Growth and growth hormone in children born small for gestational age. Acta Pediatr 2005; 94: 1348-1355.

5. Saenger P, Czernichow P, Hughes I et al. Small for gestational age: short stature and beyond. J Clin Endocrinol Metab 2007; 28 (2): 219-251.

6. NCD Risk Factor Collaboration (NCD-RisC). Trends in adult body-mass index in 200 countries from 1975 to 2014: a pooled analysis of 1698 population-based measurement studies with 19.2 million participants. 2016; 387: 1377-1396.

7. World Health Organization. Obesity and overweight. 2015.

8. González-Muniesa P, Mártinez-González MA, Hu FB, Després JP, Matsuzawa Y, Loos RJF et al. Obesity. Nat Rev Dis Primers. 2017; 3: 17034.

9. Lee PA, Chernausek SD, Hokken-Koelega AC, Czernichow P; International Small for Gestational Age Advisory Board. International Small for Gestational Age Advisory Board consensus development conference statement: management of short children born small for gestational age, April 24-October 1, 2001. Paediatrics 2003; 111 (6 Pt 1): 1253-1261.

10. World Health Organization. Definition, diagnosis and classification of diabetes mellitus and its complications: Report of a WHO Consultation. Part 1. Diagnosis and classification of diabetes mellitus. 2007

11. American Diabetes, Association. Diagnosis and classification of diabetes mellitus. Diabetes Care. 2005; 28(1): S37-42.

12. Matthews DR, Hosker JP, Rudenski AS, Naylor BA, Treacher DF, Turner RC. Homeostasis model assessment: insulin resistance and beta-cell function from fasting plasma glucose and insulin concentrations in man. Diabetologia. $1985 \mathrm{Jul}$; 28(7): 412-419.

13. Nolan JJ, Færch K. Estimating insulin sensitivity and beta cell function: perspectives from the modern pandemics of obesity and type 2 diabetes. Diabetologia 2012; 55(11): 2863-2867.

14. Wallace TM, Levy JC, Matthews DR. Use and abuse of HOMA modelling. Diabetes Care. 2004; 27(6): 1487-1495.
15. cretion and insulin sensitivity. Therapie. 2007; 62(4): 311-318.

16. Argente J, Mehls O, Barrios V. Growth and body composition in very young SGA children. Pediatr Nephrol 2010; 25(4): 679-685.

17. Won Kyoung Cho WK, and Suh BK. Catch-up growth and catch-up fat in children born small for gestational age. Korean J Pediatr. 2016; 59(1): 1-7.

18. Gallo P, Cioffi L, Limauro R, Farris E, Bianco V, Sassi R et al. SGA Children in Pediatric Primary Care. Glob Pediatr Health. 2016; 3: $2333794 X 16659993$.

19. Ibáñez L, Lopez-Bermejo A, Diaz M and de Zegher F. Catch-up growth in girls born small for gestational age precedes childhood progression to high adiposity. Fertil Steril 2011; 96(1): 220-223.

20. Deng HZ, Deng H, Su Z, Li YH, Ma HM, Chen HS et al. Insulin resistance and adiponec-tin levels are associated with height catch-up growth in pre-pubertal Chinese indivi-duals born small for gestational age. Nutrition\&Metabolism 2012; 9: 107.

21. Jaquet D, Gaboriau A, Czernichow P, Levy-Marchal C. Insulin resistance early in adulthood in subjects born with intrauterine growth retardation. J Clin Endocrinol Metab 2000; 85(4): 1401-6.

22. Blusková Z, Koštálová L, Celec P, Vitáriušová E, Pribilincová Z, Maršálková $\mathrm{M}$ et al. Evaluation of lipid and glucose metabolism and cortisol and thyroid hormone levels in obese appropriate for gestational age (AGA) born and non-obese small for gestational age (SGA) born prepubertal Slovak children. J Pediatr Endocrinol Metab 2014; 27(7-8): 693-699.

23. Hokken-Koelega AC, De Waal WJ, Sas TC, Van Pareren Y, Arends NJ. Small for gestational age (SGA): endocrine and metabolic consequences and effects of growth hormone treatment. J Pediatr Endocrinol Metab. 2004; 17(3): 463-469.

24. Van der Steen M, Smeets CC, Kerkhof GF, Hokken-Koelega AC. Metabolic health of young adults who were born small for gestational age and treated with growth hormone, after cessation of growth hormone treatment: a 5-year longitudinal study. Lancet Diabetes Endocrinol. 2017 Feb; 5(2): 106-116.

25. Bussler S, Penke M, Flemming G, Elhassan YS, Kratzsch J, Sergeyev E et al. Novel Insights in the Metabolic Syndrome in Childhood and Adolescence. Horm Res Paediatr. 2017 Aug 28. doi: 10.1159/000479510. [Epub ahead of print]

26. Reinehr T, de Sousa G, Toschke AM, Andler W. Comparison of metabolic syndrome prevalence using eight different definitions: a critical approach. Arch Dis Child 2007; 92: 1067-1072. 
Резиме

МОДЕЛ ЗА ПРОЦЕНКА НА ХОМЕОСТАЗАТА - ИНДЕКС НА ИНСУЛИНСКА РЕЗИСТЕНЦИЈА И СЕНЗИТИВНОСТ (ХОМА-ИР И ИС) КАЈ ДЕЦАТА СО ПРЕКУМЕРНА ТЕЖИНА, РОДЕНИ МАЛИ ЗА ВОЗРАСТА

\author{
Александра Јанчевска' ${ }^{1}$ Зоран Гучев ${ }^{1}$, Велибор Тасиќ ${ }^{1}$, Момир Поленаковиќ $^{2}$ \\ ${ }^{1}$ Универзитетска клиника за детски болести, Медицински факултет, Скопје, Република Македонија \\ ${ }^{2}$ Македонска академија на науките и уметностите, Скопје, Република Македонија
}

Вовед: Децата родени мали за гестациската возраст (СГА) имаат зголемена преваленца за метаболен синдром, дијабетес мелитус тип 2 (ДМ2), хипертензија, кардиоваскуларни и цереброваскуларни проблеми во адултна возраст.

Пациенти и методи: Во група од 100 деца родени мали за возраста и во друга група од 32 обезни деца, родени во термин, со нормална породилна тежина и висина, беа направени антропометриски мерења и биохемиски анализи за проценка на метаболичката состојба. Моделот за проценка на хомеостазата беше употребен за проценка на инсулинска резистенција и инсулинска сензитивност.

Резултати: Во групата од 100 СГА родени деца најдовме четири со прекумерна тежина/обезни деца $(\mathrm{M}: Ж=3: 1)$, а со нормална висина. Индексот на телесната маса (БМИ) кај сите четири деца беше над 98-иот перцентил, а БМИ з-скорот $(+2,04 \pm 0,30$ СДС). Вредноста на моделот за проценка на хомеостазата - индекс на инсулинска резистенција (ХОМА-ИР) кај сите четири деца беше покачен, 1,26-2,65 (>1). Двајца тинејџери имаа значителна хиперинсулинемија $(198 \mathrm{uIU} / \mathrm{ml}$ и $275 \mathrm{uIU} / \mathrm{ml})$ и беа лекувани со Метформин. Другите две девојчиња беа само на диетален режим и зголемена физичка активност. Проценетите вредности на индексот ХОМА-ИР $(1,26-2,65 ; \mathrm{N}<1)$ и инсулинската осетливост (ИС) $(58 \pm 17,12)$ кај четирите обезни СГА родени деца со нормална висина не се разликуваа од истите параметри кај групата од 32 обезни (М : Ж $=21: 11)$ деца (ХОМА-ИР $1,83 \pm 1,2$ СДС и ИС $82,99 \pm 64,53$ СДС), родени во термин со нормална родилна тежина и должина и актуелна висина.

Заклучоци: СГА родените деца обично се тенки. Сепак, ние кај 4\% од пациентите најдовме прекумерна телесна тежина, па дури и обезност. Две од овие деца имаат метаболен синдром. Прекумерната тежина, дебелината и метаболниот синдром кај СГА родените деца го зголемуваат ризикот за дијабетес тип 2, својствен за нив, како и за кардиоваскуларни и цереброваскуларни болести и дијабетес тип 2 во зрелоста.

Клучни зборови: мали за гестациската возраст, прекумерна телесна тежина, дебелина, кардиоваскуларни болести, шеќерна болест тип 2 